Volume 02 Nomor 01, Juni 2020 Page 26-32

Incrementapedia: Jurnal Pendidikan Anak Usia Dini

Program Studi PG-PAUD Fakultas Pedagogik dan Psikologi

Universitas PGRI Adi Buana Surabaya

http://jurnal.unipasby.ac.id/index.php/incrementapedia

e-ISSN: 2686-3146

\title{
MENGEMBANGKAN KEMAMPUAN KOGNITIF DALAM MENGENAL KONSEP BILANGAN 1 - 10 MELALUI MEDIA TELUR ANGKA PADA ANAK USIA 3 - 4 TAHUN
}

\author{
Mukhlish Safitri ${ }^{\text {a, }}$ Intan Prastihastari Wijaya ${ }^{\text {b, }}$ Dema Yulianto ${ }^{\mathrm{c}}$ \\ a,b,c PG-PAUD, FKIP Universitas Nusantara PGRI Kediri \\ lizzasafitri86@gmail.com,intanwijaya@unpkediri.ac.id,dema@unpkediri.ac.id
}

\begin{abstract}
Cognitive ability to recognize the concept of numbers is very important to be introduced early on, so children are accustomed to easily solving simple problems related to numbers. The problem found by researchers is that children have difficulty when asked to numerate objects, numerically order numbers, and connect images of objects with numbers according to the amount. In an effort to address this problem, the educator introduces new media, namely the number egg media made from used materials and designed as attractive as possible so that students were motivated to learn. This study aims to determine whether there is cognitive development in recognizing the concept of numbers 1-10 in children aged 3-4 years in the Playgroup Al-hikmah Kweden Karangrejo Ngasem District Kediri Regency between before and after the action. The research method used is classroom action research conducted in three cycles. This research involved subjects of 3-4 years old children totaling 18 students. The analysis technique in this research is quantitative descriptive technique by comparing learning completeness between the time before and after the action. The results obtained in the first cycle of $50 \%$, and in the second cycle of $63.8 \%$, while in the third cycle of $81.9 \%$. From the results of the study it can be concluded that through the egg media numbers can develop cognitive abilities in recognizing the concept of numbers 1-10 in children aged 3-4 years.
\end{abstract}

Keywords: cognitive abilities, number concepts, media egg numbers

\section{PENDAHULUAN}

Setiap tahap perkembangan anak mempunyai pengaruh terhadap tumbuh kembang anak di masa mendatang. Perkembangan anak usia dini meliputi beberapa aspek diantaranya adalah kognitif, fisik motorik, sosial emosional, agama dan seni. Dari kelima aspek tersebut, harus diawali dengan kemampuan dasar yang menjadi pondasi anak sebelum menginjak ke ketrampilan yang lebih kompleks. Untuk mengembangkan ketrampilan yang lebih kompleks pada anak usia dini diperlukan satu aspek yaitu kognitif. Kemampuan kognitif ini dapat diajarkan kepada anak didik melalui berbagai cara dengan menggunakan permainan menarik yang tanpa disadari anak telah banyak belajar (Pratiwi,
2019:229). Sedangkan Khadijah

(2016:32)

mendefinisikan kemampuan kognitif anak usia dini sebagai kemampuan anak dalam berpikir sehingga mampu memahami dunia di sekitarnya dan menambah pengetahuan anak. Kemampuan kognitif pada anak menurut Jean Piaget (dalam Sujiono, 2009:120) dapat digolongkan dalam 4 tahap yaitu tahap sensori motor, tahap praoperasional, tahap operasi konkret dan tahap operasi formal. Pada anak usia 3-4 tahun ini masuk pada tahap praoperasional yang ditandai dengan berkembangnya kemampuan anak dalam berpikir secara simbolik. Kemampuan kognitif pada anak akan berbeda-beda dalam perkembangannya, hal ini terjadi karena setiap anak akan terus berkembang untuk meningkatkan kematangan pengetahuan dan kognitifnya. 
Kemampuan kognitif anak usia dini dapat diawali dengan pengenalan konsep bilangan $1-10$. Konsep bilangan menurut Dewi (dalam Rahman, 2017:119) adalah bagian dari matematika yang diperlukan untuk menumbuh kembangkan ketrampilan berhitung dalam kehidupan sehari-hari dan merupakan pondasi untuk pengembangan kemampuan matematika awal ataupun menyiapkan anak untuk melangkah ke jenjang pendidikan dasar. Konsep bilangan ini dapat diajarkan kepada anak didik melalui 3 tahap menurut Lestari (2011: 9 dan 17) yaitu 1). membilang benda atau angka secara berurutan. 2). mencocokkan angka yang sesuai dengan jumlah benda yang dihitung. 3). melakukan perbandingan antara satu kelompok benda dengan kelompok denda yang lain. Pada penelitian ini peneliti menggunakan tahap 1 dan tahap 2 karena masih sebagai dasar dalam pengenalan konsep bilangan.

Dalam hal mengenal konsep bilangan 1-10 pada anak usia 3-4 tahun di Playgroup Al-Hikmah Kweden, kemampuan kognitif anak didik saat proses belajar mengajar tergolong sangat rendah. Anak didik mengalami kesulitan ketika diminta untuk membilang gambar benda, membilang angka secara urut, dan menghubungkan gambar benda dengan angka yang sesuai jumlahnya. Hal ini disebabkan karena kurangnya media pembelajaran yang sesuai dengan perkembangan anak didik. Anak didik belum termotivasi untuk aktif mengikuti kegiatan belajar mengajar. Sejalan dengan penelitian yang dilakukan oleh Pratiwi (2019:229) yang mengemukakan bahwa anak lebih mudah merasa bosan sehingga sering dijumpai anak yang saling bercakap-cakap dengan temannya selama kegiatan pembelajaran. Anak didik cenderung ramai, mencari mainan lain yang lebih menarik, dan tidak memperhatikan pembelajaran yang disampaikan.

Dari 18 anak didik yang diteliti, terdapat 10 anak didik yang masuk dalam kategori anak belum berkembang (BB) atau yang mendapatkan nilai 1, jumlah ini berarti lebih dari setengah dari seluruh anak didik yang diteliti. Sedangkan yang masuk dalam kategori anak mulai berkembang (MB) atau yang mendapatkan nilai 2 terdapat 4 anak didik. Sementara itu, pada kategori berkembang sesuai harapan (BSH) atau yang mendapatkan nilai 3 hanya ada 2 anak didik saja.

Berdasarkan hasil observasi yang dilakukan di Playgroup Al-Hikmah Kweden tersebut, maka kemampuan kognitif anak didik perlu dikembangkan supaya skala pencapaian perkembangan anak didik dapat maksimal, karena dari hasil observasi menunjukkan bahwa sebagian besar anak didik belum mampu membilang benda secara tepat, yaitu menunjuk benda dengan mengucapkan angka terlihat tidak bersamaan dan pada saat membilang angka juga belum berurutan. Selain itu, juga masih sering terjadi urutan angka terbolak-balik, serta belum mampu melanjutkan angka yang dibilang.

Berawal dari permasalahan tersebut di atas, maka peneliti akan mencoba membuat pembaharuan media pembelajaran untuk menunjang kemampuan kognitif dalam mengenal konsep bilangan 1-10. Seperti halnya penelitian yang dilakukan oleh Rosa (2019:86) alternatif pembelajaran sebagai berikut: 1) menggunakan media pembelajaran yang menarik, sehingga anak tertarik dan semangat untuk mencoba, 2) pembelajaran melibatkan anak secara aktif dalam 
kegiatan. Peneliti menggunakan media pembelajaran yang diharapkan dapat mendorong anak didik untuk semangat dan aktif belajar. Media pembelajaran menurut Guslinda (2018: 3) yaitu suatu bentuk peralatan, metode atau cara yang digunakan dalam menyampaikan pesan, membantu memperjelas maksud dari pelajaran, sehingga menggugah minat dan motivasi anak didik selama proses belajar mengajar berlangsung. Media yang dipilih pada penelitian ini dinamakan media telur angka. Media telur angka ini merupakan media yang menggunakan bahan utama berupa telur ayam tiruan terbuat dari plastik yang diletakkan dan disusun pada sebuah meja lipat bekas. Selain itu, media telur angka ini sangat berkesan bagi anak usia dini dikarenakan dibuat dengan warna dan bentuk yang unik. Media ini dilengkapi dengan ayam tiruan (boneka ayam) supaya membuat media lebih hidup menyerupai aslinya dan menarik karena anak usia dini belajar melalui bermain dengan benda konkret di sekitarnya. Tugas anak dalam pembelajaran melalui media telur angka adalah membilang telur, membilang angka $1-10$, dan menghitung jumlah benda sesuai angka yang muncul.

Seperti inilah gambar media telur angka yang dapat digunakan untuk:

1. Membilang telur

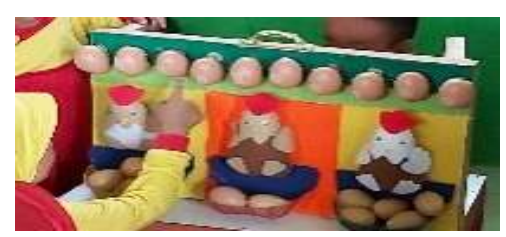

Gambar 1. Membilang telur

2. Membilang angka

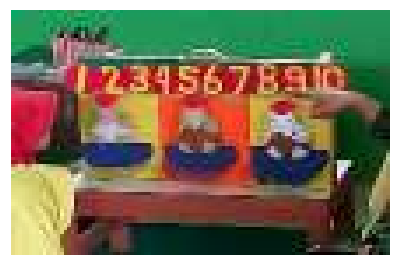

Gambar 2. Membilang angka

3. Menghitung jumlah telur sesuai angka yang muncul

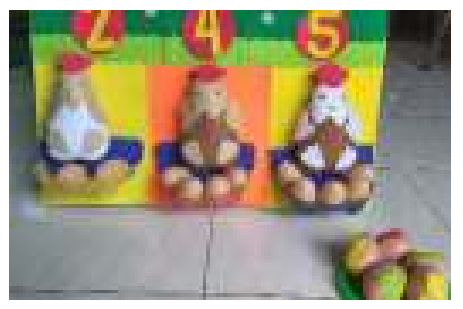

Gambar 3. Menghitung jumlah telur sesuai angka yang muncul

Media Telur Angka ini dirancang sedemikian rupa supaya mudah untuk digunakan oleh siapapun. Cara penggunaannya adalah sebagai berikut:

1. Anak didik diminta untuk membilang secara urut telur yang sudah tertempel.

2. Anak didik diminta untuk membilang secara urut angka yang sudah tertempel.

3. Anak didik diminta untuk mengambil telur angka secara acak di toples. Anak didik diminta untuk menebak berapa angka yang diambil itu. Kemudian mengambil dan menghitung telur sesuai jumlah angka dan diletakkan tempat telur di bawah boneka ayam.

Berdasarkan latar belakang yang telah dijelaskan, maka dapat dijabarkan rumusan masalah pada penelitian ini adalah apakah dengan menggunakan media telur angka dapat mengembangkan kemampuan kognitif dalam mengenal konsep bilangan 1-10 pada anak usia 3-4 tahun?.

Tujuan dari penelitian ini adalah untuk mengetahui ada tidaknya perkembangan kognitif dalam mengenal konsep bilangan 1-10 pada anak usia 3-4 tahun di Playgroup Al-hikmah Kweden Karangrejo Kecamatan Ngasem Kabupaten Kediri antara sebelum dan sesudah dilakukan tindakan. 
Sedangkan manfaat penelitian ini bagi pendidik adalah 1). Dapat menambah referensi media pembelajaran baru untuk mengembangkan kemampuan kognitif dalam mengenal konsep bilangan 1-10 pada anak usia 3-4 tahun. 2). Dapat menambah wawasan tentang pentingnya media pembelajaran untuk mengembangkan kemampuan kognitif dalam mengenal konsep bilangan $1-10$ pada anak usia 3-4 tahun. Sementara itu, manfaat bagi anak didik yaitu 1). Memberikan media baru dalam pembelajaran. 2). Dapat menciptakan pembelajaran yang aktif dan intraktif. 3). Menimbulkan kegairahan dan motivasi dalam belajar. 4). Memberi rangsangan, pengalaman dan persepsi yang sama bagi anak. 5). Menghilangkan rasa bosan dalam belajar dan lebih tertarik belajar tentang konsep bilangan.

Hipotesis tindakan yang disusun dalam penelitian ini yaitu: "Tindakan pembelajaran melalui media telur angka dapat mengembangkan kemampuan kognitif dalam mengenal konsep bilangan 1 sampai 10 pada anak usia 3-4 tahun Playgroup Al-Hikmah Kweden Kabupaten Kediri”.

\section{METODE PENELITIAN}

Jenis penelitian yang digunakan adalah penelitian tindakan kelas dengan teknik analisis deskriptif kuantitatif menggunakan model Kemmis dan Taggart

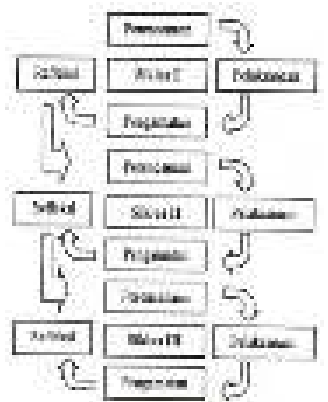

Gambar 4. Model Kemmis dan Taggart
Menurut model Kemmis dan Taggart dalam Arikunto (2015:42), pada gambar 1 di atas alur penelitian itu terdiri dari empat tahap yaitu perencanaan, pelaksanaan, pengamatan, dan refleksi yang dilakukan sebanyak 3 siklus yaitu Siklus I, Siklus II, dan Siklus III. Pada penelitian ini, peneliti melakukan pengumpulan data tentang kemampuan kognitif dalam mengenal konsep bilangan 1 sampai dengan 10 pada anak usia 3-4 tahun pada kelompok Playgroup Al-Hikmah Kweden ini menggunakan teknik unjuk kerja dengan cara anak didik untuk melakukan tugas dan perbuatan yang diamati oleh pendidik. Sedangkan pengumpulan data tentang pelaksanaan pembelajaran diperoleh dengan cara teknik observasi menggunakan lembar observasi. Selain itu, penelitian ini menggunakan teknik analisis data untuk menguji hipotesis tindakan yaitu teknik deskriptif kuantitatif dengan cara membandingkan ketuntasan belajar (persentase yang memperoleh nilai $3=$ BSH dan nilai $4=\mathrm{BSB}$ ) antara waktu sebelum dan sesudah dilakukan tindakan siklus I, tindakan siklus II dan tindakan siklus III. Berikut ini adalah langkah-langkah analisis data yang digunakan:

Menghitung persentase anak didik yang mendapat nilai 1 ( $\mathrm{BB}=$ Belum Berkembang), nilai 2 $(\mathrm{MB}=$ Mulai Berkembang), nilai 3 (BSH = Berkembang Sesuai Harapan), dan nilai 4 (BSB = Berkembang Sangat Baik) menggunakan rumus di bawah ini:

$\mathrm{P}=\underline{((\mathrm{n} \times 4)+(\mathrm{n} \times 3)+(\mathrm{n} \times 2)+(\mathrm{nx} 1))} \times 100 \%$

(Nx skor tertinggi)

Keterangan :

$\mathrm{P}=$ persentase anak didik yg mendapat nilai tertentu $\mathrm{n}=$ jumlah anak didik yang mendapat nilai tertentu $\mathrm{N}=$ jumlah anak didik keseluruhan 


\section{HASIL PENELITIAN}

Penelitian yang dilakukan oleh peneliti ini menggunakan 3 siklus. Setiap siklusnya terdiri dari 4 tahap yaitu yang pertama tahap perencanaan yang meliputi penyusunan RPPM, RPPH, menyiapkan media telur angka, dan menyiapkan instrumen penilaian. Kedua, tahap pelaksanaan yang berisi tentang penjelasan tema, penjelasan media telur angka, tata cara menggunakan media. Ketiga, tahap pengamatan meliputi pengamatan kemampuan kognitif anak dalam mengenal konsep bilangan. Keempat, tahap refleksi yaitu meninjau kembali dari pengamatan yang diperoleh dan permasalahan yang timbul pada saat kegiatan pembelajaran berlangsung, akan menjadi dasar untuk melakukan perencanaan ulang pada siklus berikutnya. Melakukan beberapa perbaikan supaya permasalahan dapat teratasi dan tidak tampak lagi pada siklus selanjutnya. Siklus I pada penelitian ini dilakukan pada tanggal 27 Januari 2020, siklus 2 pada 3 Februari 2020 dan siklus 3 pada 10 Februari 2020 sehingga dihasilkan data sebagai berikut:

Tabel 1. Hasil Penilaian Unjuk Kerja Kemampuan Mengenal Konsep Bilangan 1-10 menggunakan media telur angka

\begin{tabular}{|c|c|c|c|c|c|c|}
\hline \multirow{2}{*}{ No. } & \multirow{2}{*}{ Perilaku yang diamati } & \multicolumn{4}{|c|}{ Frekuensi } & \multirow{2}{*}{$\begin{array}{c}\text { Persentase } \\
\text { Keberhasilan }\end{array}$} \\
\hline & & BB & MB & $\mathrm{BSH}$ & BSB & \\
\hline Siklus & Kemampuan & & & & & \\
\hline I & $\begin{array}{l}\text { Mengenal Konsep } \\
\text { Bilangan } 1-10 \\
\text { menggunakan media } \\
\text { telur angka }\end{array}$ & 9 & 3 & 3 & 3 & $50 \%$ \\
\hline $\begin{array}{l}\text { Siklus } \\
\text { II }\end{array}$ & $\begin{array}{l}\text { Kemampuan } \\
\text { Mengenal Konsep } \\
\text { Bilangan 1-10 } \\
\text { menggunakan media } \\
\text { telur angka }\end{array}$ & 4 & 5 & 4 & 5 & $63,8 \%$ \\
\hline $\begin{array}{l}\text { Siklus } \\
\text { III }\end{array}$ & $\begin{array}{l}\text { Kemampuan } \\
\text { Mengenal Konsep } \\
\text { Bilangan 1-10 } \\
\text { menggunakan media } \\
\text { telur angka }\end{array}$ & 1 & 3 & 4 & 10 & $81,9 \%$ \\
\hline
\end{tabular}

Keterangan:

$\mathrm{BB}=$ Belum Berkembang

$\mathrm{MB}=$ Mulai Berkembang

$\mathrm{BSH}=$ Berkembang Sesuai Harapan

$\mathrm{BSB}=$ Berkembang Sangat Baik

Dapat dilihat dari tabel 1 bahwa persentase keberhasilan anak didik di siklus I, siklus II dan yang terakhir siklus III perlahan-lahan mengalami peningkatan.

Bukti dokumentasi kegiatan yang dilakukan anak didik dalam mengenal konsep bilangan menggunakan media telur angka dapat diamati pada gambar-gambar di bawah ini:

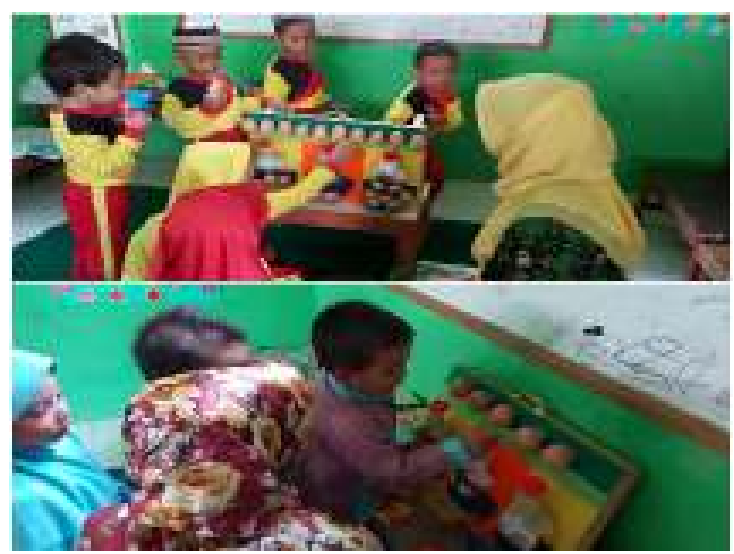

Gambar 5. Anak membilang telur

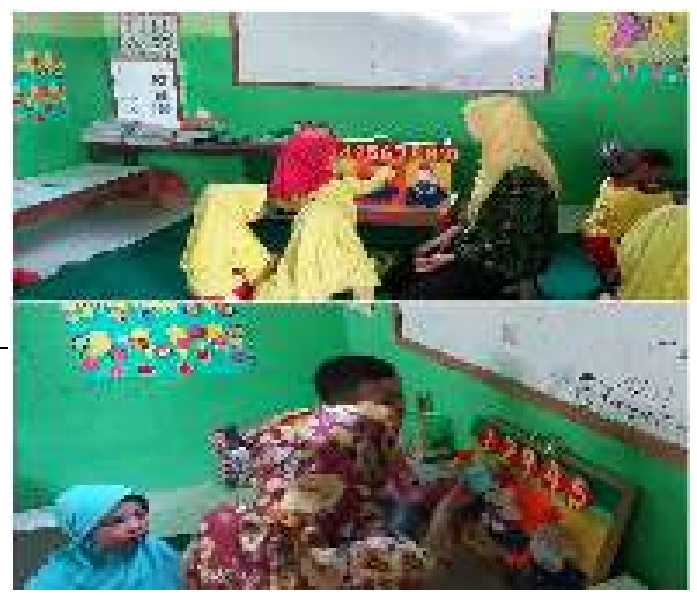

Gambar 6. Anak membilang angka 


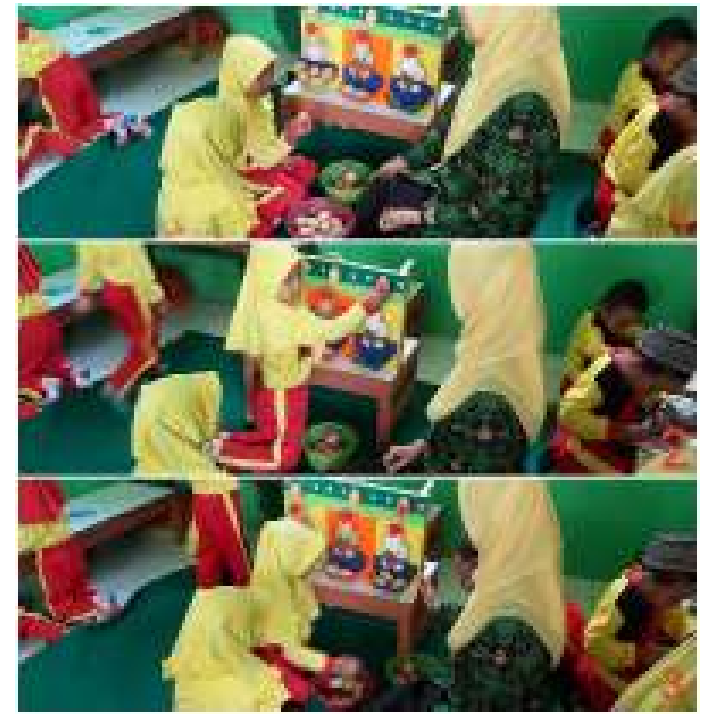

Gambar 7. Anak mengambil telur secara acak dan menebak angka yang muncul. Telur ditempel dipapan kemudian anak menghitung telur sesuai angka yang tertempel.

\section{PEMBAHASAN}

Dari tabel 1 di atas yaitu hasil penilaian unjuk kerja kemampuan mengenal konsep bilangan 1-10 menggunakan media telur angka pada siklus I sebesar 50\% yang tergolong dalam kategori masih rendah. Selanjutnya, pada siklus II mengalami peningkatan $13,8 \%$ sehingga menjadi $63,8 \%$ tetapi belum memenuhi kriteria ketuntasan belajar. Kemudian pada siklus III terdapat peningkatan lagi sebesar $18,1 \%$ sehingga pencapaian persentase pada siklus III yaitu $81,9 \%$ dan sudah melampaui ketuntasan belajar yaitu $75 \%$.

Jika ditampilkan dengan menggunakan grafik akan seperti di bawah ini :

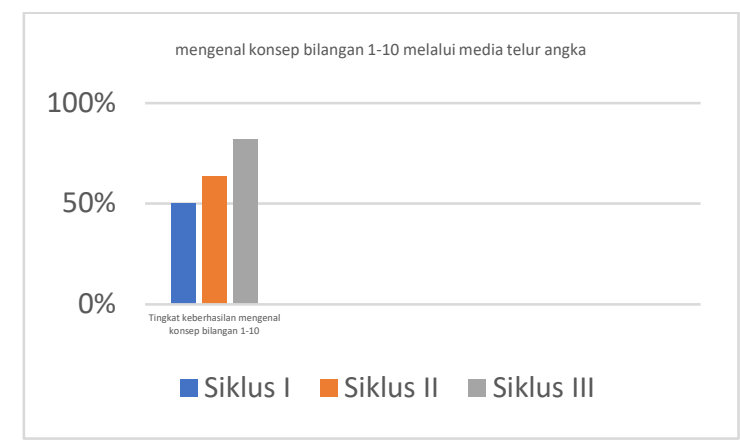

Grafik 1. Mengenal konsep bilangan melalui media telur angka
Pada siklus III diperoleh persentase yang melampaui ketuntasan belajar sehingga hipotesis yang berbunyi "Tindakan pembelajaran melalui media telur angka dapat mengembangkan kemampuan kognitif dalam mengenal konsep bilangan 1 sampai 10 pada anak usia 3-4 tahun Playgroup Al-Hikmah Kweden Kabupaten Kediri dapat diterima".

\section{SIMPULAN DAN SARAN}

\subsection{Simpulan}

Berdasarkan hasil analisis data yang didapatkan oleh peneliti menunjukkan bahwa tindakan pembelajaran melalui media telur angka dapat mengembangkan kemampuan kognitif dalam mengenal konsep bilangan 1-10 pada anak usia 3-4 tahun Playgroup Al-Hikmah Kweden Kabupaten Kediri.

\subsection{Saran}

Berdasarkan temuan penelitian ini dapat direkomendasikan sebagai bahan pertimbangan dalam mengembangkan kemampuan kognitif dalam mengenal konsep bilangan pada penelitian selanjutnya.

\section{PERNYATAAN TERIMA KASIH}

Ucapan terima kasih kepada Allah SWT yang telah memberikan kelancaran dalam menyelesaikan artikel ini. Kepada keluarga yang telah memberikan semangat dalam terselesainya artikel. Tidak lupa kepada dosen pembimbing I yaitu Ibu Intan Prastihastari Wijaya, M.Pd., M.Psi dan dosen pembimbing II yaitu Bapak Dr. Dema Yulianto, M.Psi yang senantiasa memberikan bimbingan dan pengarahan. Serta teman-teman semuanya yang telah memberikan dukungan pada penelitian ini. 


\section{REFERENSI}

Arikunto, Suharsimi dkk. (2015). Penelitian Tindakan Kelas Edisi Revisi. Jakarta: Bumi Aksara

Guslinda dan Rita Kurnia. (2018). Media Pembelajaran Anak Usia Dini. Surabaya: Jakad Publishing

Khadijah. (2016). Pengembangan Kognitif Anak Usia Dini. Medan: Perdana Publising

Lestari. (2011). Konsep Matematika Untuk Anak Usia Dini. Kementerian Pendidikan Nasional

Pratiwi, Neni. (2019). Peningkatan Kemampuan Kognitif Melalui Permainan Roda Putar Pada Anak Kelompok A Di Tkn Pakunden 1 Kota Blitar. Jurnal Pendidikan Riset dan Konseptual. Vol 3 No 3, Oktober 2019

Rahman, Taopik dkk. (2017). Peningkatan Kemampuan Anak Usia Dini Mengenal Konsep Bilangan Melalui Flashcard. Jurnal PAUD Agopedia UPI Kampus Tasikmalaya

Rosa, Eggie Mitha dan Usep Kustiawan. (2019). Peningkatan Kemampuan Mengenal Konsep Bilangan Melalui Media Kreasi Flipbook Anak Kelompok A. Jurnal Pendidikan Anak Usia Dini. Vol 1, no 2, 2019, hlm. 86-94

Sujiono, Yuliani Nurani. (2009). Konsep Dasar Pendidikan Anak Usia Dini. Jakarta Barat: Indeks 